\title{
"Like a newborn baby": Using Journals to Record Changing Identities Beyond the Classroom
}

Martin Andrew

The purpose of this article is to describe the sociocultural learning of 40 secondyear students in a Bachelor of Arts in English-as-an-additional-language (EAL) program in Auckland, New Zealand. These learners participated in a teaching and learning intervention involving journalized community placement. The study illustrates how reflective journals can be used as a vibrant teaching, learning, and assessment tool, enabling students to make connections with the culture of their host country, to reflect on their experiences of language socialization, and to become aware of their own investments. Students from the four categories of EAL learner (immigrants, international students, study-abroad students, and refugees) participated in a real-world community/workplace writing reflective diaries recording their observations and interactions. Qualitative analysis using discourse positioning reveals students describing themselves in relation to themes of changing perceptions of English abilities, changing identities relative to the host culture, and participation as socialization. The article concludes that writing reflective journals helps learners to evaluate how far they have come as learners and citizens and to find spaces for the enhancement of human possibility (Norton, 2000). The practical pedagogical implication of the study is that combined with journaling, community placements contribute to a positive, future-focused "pedagogy for authentic being" (Barnett, 2004).

L'objectif de cet article est de décrire l'apprentissage socioculturel de 40 étudiants en deuxième année dans un programme de B.A. en anglais langue additionnelle à Auckland, en Nouvelle-Zélande. Ces apprenants ont participé à une intervention pédagogique consistant en un stage communautaire documenté dans un journal. L'étude illustre l'emploi de journaux de réflexions comme outils d'enseignement, d'apprentissage et d'évaluation qui permettent aux étudiants d'établir des liens avec la culture de leur pays hôte, de réfléchir sur leurs expériences de socialisation langagière et de se rendre compte de leurs propres investissements. Des étudiants représentant les quatre catégories d'apprenants d'anglais comme langue additionnelle (immigrants, étudiants internationaux, étudiants dans le cadre d'un échange, réfugiés) ont participé à un stage communautaire/dans un milieu de travail et ont noté leurs observations et leurs interactions dans un journal de réflexion. Une analyse qualitative reposant sur le positionnement du discours a révélé que les étudiants se décrivaient en fonction 
de thèmes portant sur leurs perceptions changeantes de leurs capacités en anglais, sur leurs identités changeantes par rapport à la culture hôte, et sur la participation comme socialisation. L'auteur conclut que la rédaction de journaux de réflexion aide les étudiants à évaluer leur cheminement comme apprenants et citoyens, et à trouver des marges pour l'amélioration du potentiel humain (Norton, 2000). La conséquence pédagogique pratique de l'étude consiste en la conclusion que les journaux de réflexion, employés dans le contexte d'un stage communautaire, contribuent à une "pédagogie de l'être authentique » qui est positive et orientée vers l'avenir (Barnett, 2004).

\section{Community Placement in Language Teaching}

When I first came to NZ, I didn't know anything I was like a newborn baby and having this job helped me to understand and realize things that contribute to the culture of a country. It's a stepping stone in my discovery of NZ culture and society. (Andreas, Romania, participant in community placement)

Andreas is one of 40 immigrants, international students, study-abroad students, or refugees who wrote reflective journals about their experience of participating in a community placement as a way of learning about New Zealand's local and national culture and its people's distinctive ways of speaking and being.

Community placement is recognized in Canada as offering individuals "the opportunity to gain valuable experience, references, employment-related skills; [to] build basic networks; and to contribute to their community, while increasing their chances of obtaining employment" (County of Wellington, 2011). In contexts of teaching and learning English as an additional language (EAL), community placements are, like work placements, course-related, organized learning opportunities in which participants spend a specified period in a chosen environment, local community, or workplace to achieve sociocultural and sociolinguistic goals.

Students effectively take part in a community of practice (Lave \& Wenger, 1991; Wenger, 1998), participating in the endeavors, enterprises, and discourses of the community and moving from "legitimate peripheral participation" to a deeper, invested interest involving "the whole person acting in the world" (Wenger, p. 98). Students participate in "language socialisation" (Duff, 2007), more accurately sociocultural socialization (incorporating language). In such communities, local people go about "getting their acts together" (Gee, 1996, p. 155). Andreas' case reveals that by encountering and participating in the discourses of community members, he can "understand and realize things that contribute to the culture of a country." 
ways of behaving, interacting, valuing, thinking, believing, speaking, and often reading and writing, that are accepted as instantiations of particular identities by specific groups. They are "ways of being" in the world; they are "forms of life"; they are socially situated identities. (Gee, 1996, p. 3)

Community placements open EAL learners to the situated identities, ways of being, and forms of life of discourses. They expose them to social, cultural, and linguistic authenticity in the core features of Wenger's (1998) community of practice: mutual engagement (the regular interactions of community members), joint enterprise (the members' common endeavor, goal, vision, or pursuit) and shared repertoire (ways of thinking, speaking, and expressing common to a community).

\section{The Purpose of the Study}

This study exemplifies how community placements embody "a chance for learners to observe and participate in activities that happen normally as part of the regular operation of a group interacting, communicating and socialising at a particular site" (Andrew \& Kearney, 2007, p. 32). It aims to demonstrate how students such as Andreas can develop from the reported tabula rasa of "a newborn baby" to become an understanding contributor to a community. The study maintains that community placements can act as stepping stones to a process of knowing oneself relative to one's host culture. Specifically, it shows how the use of journals to record experiences of community placements points to pedagogical and practical implications not only for exposing learners to authentic discourse, traits of culture, and practical skills, but also for understanding the self and others through an act of written re-creation.

This article is about insights recorded in reflective journals during and after community placements. It both valorizes community placements as an alternative, culturally sensitive intervention, preparing students for participation in the social world and its desired and idealized "imagined communities" (Anderson, 1983), and examines the themes of the journals that students wrote during placements. The evidence for the pedagogical claims lies in the writings themselves: 40 reflective and narrative records of 10 or more hours of participating in a community environment. This study shows how journals written during community placements set learners on a controlled journey "of encountering strangeness, of wrestling with it, and of forming [their] own responses to it" (Barnett, 2004, p. 257), of creating opportunities for the "unfamiliar freedom" that Dlaska (2000, p. 258) argues is a prerequisite for independent culture-learning. The journals trace a journey of encountering otherness and strangeness, of learning by noting contrasts 
with participants' home culture; a journey of becoming, providing "an experience of identity" (Wenger, 1998, p. 215). Insights in journals like that of Andreas articulate moments of surprise and stimulate reflection on realizations about identity.

The research question is threefold: What insights do writers of journals reflecting on community placements reveal about (a) their changing perceptions of their English abilities, (b) their own identities relative to their host country, and (c) their understandings about how participation socializes them into the discourses of their communities?

In the following section, I offer specific background to the study. I then situate the study in the literature on learners expressing identity through acts of writing such experiential genres as journals and autobiographies and consider the role of reflection. I introduce the participants, describe the methodology, and present findings corresponding to the research question. Then follows a discussion of the significance of the findings to current understandings about the practical usefulness of community placement for linguistic and cultural learning, and of the pedagogical value of journal-writing for language-learners on the cusp of a new culture.

\section{Background}

Particularly in tertiary environments, the language-teaching industry has an increasing need for pedagogical interventions that encourage learners' agentiality in discovering the cultural and linguistic features of their host country (Dlaska, 2000; Sercu, 2002). Intercultural Communicative Language Teaching (Newton, Yates, Shearn, \& Nowitzki, 2010) stresses that "culture is no longer an invisible or incidental presence in language learning but instead is ... a strand with equal status to that of language" (p. 1). The pedagogic use of journals in placements responds to the calls of researchers in lived literacy practices (Barton, Hamilton, \& Ivanic, 2000; Gee, 1992) and sociocultural theory (Gee, 1996; Kramsch, 1998; Pavlenko \& Lantolf, 2000; Pittaway, 2004; Swain, Kinnear, \& Steinmann, 2010) to acculturate EAL learners to language situated in the social world. Peterson and Coltrane (2003) argued that such instruction should "allow students to observe and explore cultural interactions from their own perspectives to enable them to find their own voices in the second language speech community" (p. 2).

Globalization continues to affect both export education, including studyabroad programs, and education for immigrants and refugees in such countries as New Zealand, Australia, and Canada. This brings the challenge to supply social and cultural capital, in this case to those invested in learning in degree-level EAL courses. First, immigrant learners (and second, refugees) need to learn about the social systems, institutions, and social/workplace practices of their new country. Next, international students need to experience their host culture deeply and to interact closely with its people so that 
they can situate themselves as effective global citizens in their future communities, in their home countries, or wherever they migrate. Fourth, study-abroad students sponsored international students with investments in learning overseas commonly report a desire for cultural immersion, which often involves an impetus to learn about culture from travel as well as from classroom participation (Hartmann, 2010). Pittaway (2004) describes the outcomes of such an investment-focused pedagogy: "The process has the power to orient classroom practice in a way that truly acknowledges students for the complexity underlying their motivations, desires, and hopes for the future" (p. 216).

Research shows that social contact with local people aids the coping mechanisms of international students (Furnhan, Bochner, \& Lonner, 1986) and, moreover, affects their communicative competence (Zimmermann, 1995). Pavlenko (2002) emphasizes that social interaction is crucial for L2 learning. Research also suggests that students strongly desire more contact (Blue, 1990), particularly with native English-speakers (Heikinheimo \& Schute, 1986) and especially in the social world (Cooke, 2001). Without supportive intervention, they may feel like outsiders. Myles and Cheng (2003) wrote:

If they want to feel more like "insiders," they need to participate in a host cultural milieu in order to acquire new cultural knowledge, cultivate greater emotional and aesthetic sensitivity and expand the range of their behavioural repertoire. (p. 258)

Volunteer placements for L2 learners, however, need to be arranged with care in order to ensure success (Dudley, 2007).

In countries such as Canada, New Zealand, and Australia, placements can offer a student pedagogical, curricular, and/or assessment opportunity to foreground experiences of culture and language by participating in a host culture. What might seem merely an imagined community to students can become an empowering reality with community placements. They are an integral part of a Bachelor of Arts (EAL) at Unitec New Zealand, in a unit investigating the country's Maori and bicultural heritage, multicultural migration history, media and arts, social and political institutions, those who have made a contribution to culture, and so forth. Culture, like identity, is not monolithic. With Keesing (1982), the program views culture as "ordered not simply as a collection of symbols fitted together ... but as a system of knowledge, shaped and constrained by the way the human brain acquires and processes information and creates internal models of reality" (p. 59).

Placements provide contexts in which learners participate in a community and develop independent understandings of Kiwi culture by interacting in the L2 speech community and experiencing its practices. With support from lecturers, students choose volunteer help groups (such as Citizens' Advice Bureaux, New Zealand Federation for the Blind); volunteer programs run by cultural sites (museums, aquaria, environmental groups); charity and aid or- 
ganizations such as the Red Cross; clubs (soccer and racing clubs); church groups and Christian communities; lobby groups (initiatives organized by the police, refugee support groups, or environmental action groups); and workplaces (nursing homes, preschool programs, and schools, including language schools).

\section{Theoretical Frame}

Although sociocultural language socialization (Duff, 2007) provides a major framework for understanding connections between participation in community and identity, this study draws on poststructuralist understandings of learners' identities as multiple, complex, in flux, and subject to desire and discourses of power. These understandings establish connections between language and power, cultural awareness, social dynamics, and identity negotiation (Morita, 2004; Norton, 2010; Pavlenko, 2002). The project is also informed by Lavian/Wengerian social constructivism and insights into literacy practices that view the co-construction of sociocultural awareness as situated learning.

Writing a journal affords learners a "unique means of self-representation" (Pavlenko, p. 285). It offers chances to negotiate "socially available possibilit[ies] for selfhood" (Ivanic, 1998, p. 27). When community placement students write in their journals about their experiences, observations, and learning, they participate in a reflective process of recognizing both their place in their (and others') communities and their identities in relation to their life journeys. Norton's (2000) immigrant women adjusting to a new culture and language revealed emergent identities. Through writing journals, they described their investments in learning the target language, and through reflective writing, they reframed their relationships with native speakers. Norton's participants also related their "surprises" about language, culture, and themselves. The journals produced in Pavlenko's, Ivanic's and Norton's studies showed students charting their sociocultural learning through the act of autobiography. Sending EAL students into the community to record their stories of diversity can make students nomadic "ethnographers of difference" engaged with their processes of "becoming" (Grey, 2009).

Pavlenko and Lantolf (2000) showed that reflective autobiographical writing captures the process of language use as social practice and as a site of identity construction. Learning an L2 and the attendant cultural awareness is enhanced when a learner/participant establishes social value in a community of practice (Lave \& Wenger, 1991; Wenger, 1998). Much research has investigated the effect of participation in communities on identity (Andrew \& Kearney, 2007; Haneda, 1997; Morita, 2004; Norton, 2001). Researchers suggest that the resulting imagining of participation in future communities can stimulate investment (Kanno \& Norton, 2003; Li, 2009; Norton \& Toohey, 2001). In this study, journals map a journey of self, involving the writer/subject as 
a student/learner and a participant/community member. Such a map tells us about learners' perceived gains in cultural capital, changing identities, and desires for belonging (Norton, 2000).

What most students write is a socioculturally situated autobiographical narrative of their interactions. Pavlenko and Blackledge (2005) label this process of positioning oneself in discourse as "reflective positioning" (p. 20). In the writing process, participants create a subject position: themselves as learners and individuals in process, as in Kristeva's (1986) understanding of subjectivity. This resonates with Benson's (2005) definition of EAL autobiography as focusing on "the analysis and description of social phenomena as they are experienced within the context of individual lives" (p. 4) and with Wenger's (1998) description of identity as "a way of talking about how learning changes who we are and creates personal histories of becoming in the context of our communities" (p. 5).

\section{Methodology}

\section{The Participants}

Forty students from six intakes over three years participated in the community placement journal project. All were second-year Bachelor of Arts (EAL) learners with academic IELTS bands of 6.0 or above (or equivalent). They represented the following ethnocultural backgrounds: Chinese (18, with 2 others identifying as Taiwanese and 2 as from Hong Kong), Korean (5), Swedish (5), German (2), Ethiopian (1), Somalian (2), Thai (1), Malaysian (1), and Samoan (1). The 26 women and 14 men ranged in age from 20 to 55, with a mean age of 25 years. Twenty were migrants, 10 international students, seven study-abroad students, and three refugees.

\section{Data Collection}

The participants were all registered in a 12-week course that contextualized Kiwi culture historically rather than freeze-framing it in stasis. Lecture topics included: varying responses to the Treaty of Waitangi; New Zealand's ongoing settlement history; the changing environment and the Green and Antinuclear movements; stories of New Zealand's multicultural writers, master carvers, and film-makers; deconstruction of Kiwi humor, symbols, and iconography; and analysis of New Zealand's changing societal systems.

The data derive primarily from learners' journals written while and after participants completed a 10-hour community placement. Evidence portfolios of photographs, supervisors' references, and site documents were also collected. The placements occurred mostly during term breaks, and most students exceeded the minimum of 10 hours, with some becoming long-term volunteers. Participants were required to write four journal entries of 250 words each. In their journal entries, students commented and reflected on their observations and experiences. They were encouraged to include aspects 
that they considered noteworthy, different from their own culture, or specifically Kiwi: use of language, voice, and idiom; the topical and communicative content of spoken interactions; communication styles and strategies; ways of behaving, interacting, and socializing; pragmatic knowledge or skills that they developed during placement; and any revelations or surprises. All students gave their permission for their words to be cited; all names are pseudonyms.

\section{Reflection}

In order to write such a personal history, students needed to place themselves as reflective subjects in their narratives. Kathpalia and Heah (2008) argue that providing clear definitions of reflection is essential if students are to understand the linguistic, cognitive, affective, and social dimensions. Students applied a definition by Boude, Keogh, and Walker (1985): reflection is "a generic term for those intellectual and affective activities in which individuals engage to explore their experiences in order to lead to new understandings and appreciations" (p. 19).

\section{Data Analysis}

We located the research in the interpretative paradigm and sought to understand the participants and their situated and social learning through their own words and perspectives (Hitchcock \& Hughes, 1993). The students' journals comprised thick descriptions (Denzin \& Lincoln, 2000) wherein they reflectively positioned themselves as subjects in a cumulative narrative. In these data, learners' experiences and identities were grounded in story lines set in social contexts (Pavlenko, 2001), so a method of data analysis was developed based on discursive positioning, which emphasizes our multiple community affiliations and changing selves (Davies \& Harre, 1990). The students reflectively positioned themselves, and "a person inevitably sees the world from the vantage point of that position and in terms of the particular images, metaphors, storylines and concepts which are made relevant within the particular discursive practice in which they are positioned" (p. 46). Analysis of learners' discursive reflective positions allowed us to appreciate the uniqueness of stories, while acknowledging that useful knowledge derived from identifying recurrent themes. The method begins with one used by Sandelowski (1995) to interpret texts generated in nursing: reading the material, identifying key storylines to understand everyday practices, and underlining key phrases "because they [made] some as yet inchoate sense" (p. 373).

Discursive positioning allows researchers to use linguistic means to locate writers' reflective positioning. Linguistic signals such as comparative adjectives and adverbs, for example, alert researchers to instances of increased cultural capital. References to community-specific shared repertoire or unfamiliar lexis and idioms signal further changing perceptions. Similarly, shifts in tense clearly indicate a then-and-now contrast; and particularly in learner texts at this level, discourse markers signal logical functions, with but or 
whereas marking a perceived contrast. Based on a frequency count, subcategories logically emerge from the broad core categories changing perceptions of English abilities, changing identities relative to the host culture, and participation in community as socialzsation. I use these to organize the findings.

\section{Findings}

\section{Changing Perceptions of English Abilities}

All respondents described with reflective clarity their awareness of how they had acquired aspects of language and culture. The following three sub-categories illustrate students' socializing into discourses by applying communicative and lexical strategies from the classroom and connecting aspects of culture taught with what they experienced.

\section{Communication strategies}

The most significant finding about language acquisition lies in students' descriptions of the strategies used to increase their communication. Twentyeight students described applying strategies such as increasing the volume of their voice, checking the functional intonation of their enquiries, using body language, using polite language, and monitoring register. Robina (China), for example, discovered that regardless of the spoken interaction, people understand from context: "I think sometimes the language of the heart can really work out the meaning between people." Similarly, Celine (China), working in a café, used the repetition gambit "Could you say that again, please?" with a woman who asked for "botter" before realizing that she was hearing the Kiwi pronunciation of butter. Katrina (Taiwan), running a cleaning business, learned the value of direct politeness: "I found, from my experience, when Kiwis make a request, the language they use is polite, but they will express their meaning directly and clearly."

\section{Lexical acquisition}

Because they believed that they were unable to understand spoken English, specifically regionalisms, the learners provided many stories of how they learned new lexis or idioms through interaction with fellow volunteers, supervisors, customers, or others whom they encountered. Working in a shared repertoire is itself constructive, as corroborated by Sonja's (Taiwan) experience of working in a warehouse: "The language I use is quite specific but I really learnt and improved my confidence every time ... I believe I cannot speak well if I did not do this job ... as well as learn new vocabulary." Similarly, Toby (Germany), a volunteer for the Maritime Museum, learned such words as line, throat, and topping lift through sailing with Kiwis, and Andy (Hong Kong), placed in a bakery, moved on from learning frittata, bacon and egg square and jam donut (the second of these is a Kiwi specialty) to using the barista jargon of one shot of black coffee plus half trim milk plus half full blend milk. 
In a similar vein, Pete (China), working in a nursing home, offered a typical story.

I also had to learn some food names. I gave a resident a scone after I told her I would give her cake. Before we sent back the food trolley, a co-worker asked me: "Do you fancy a scone?" I had no idea what she wanted me to do. And then I learned many alternatives to say this: "Are you fond of ...?" "Would you like ...?"

Sophia (China), volunteering for the Chinese Conservation Education Trust, used her classroom-taught skill of "deducing words from context to understand" both colloquialisms (nagging, dodgy) and a Maori word in its noun form (motu, island/land). Finally, Les (China), working in a community center, startled his supervisor by using a Kiwi-ism he had picked up during his time there. When a boy racer screeched by, he said "What a hoon!" and records his supervisor's surprise that a Chinese man would utter such a Kiwi-ism.

\section{Cultural awareness}

Thirty students remarked on increased sensitivity or awareness of either culture in general or New Zealand culture in particular. A citation from Toby is typical, and the discourses he encountered belong to the shared repertoire of his community.

Altogether the benefits of the community placement have been huge. I have learned so many things about sailing and sailing language, I met so many people and I learned a lot about New Zealand in general ... It soon started to be real fun with the opportunity to prove things from the classroom and from travel books and to enjoy society, language, behavior, and lifestyle.

Martinus (Sweden) expressed surprise at communicating with locals: "The real experience was to actually interact with people and culture." The words real and actually expressed surprise as well as awareness that language socialization happens in the real world. Rama (Samoa) attended a workshop at her Community Center and commented, "It indicates that ethnicity is a choice of identity and be aware of what you lost of identity and how to stop losing more. Therefore, how I can identify my identity and how to keep it become critical issues for my life?" Similarly, Spring (China), a Citizens' Advice Bureau volunteer, wrote, "I noticed that culture affects identity and values hierarchy ... People have their own various sets of values and these differences are OK." Rama reflected on her own "cultural maintenance," and Spring learned the importance of respecting cultural diversity. 


\section{Changing Identities Relative to the Host Culture}

Writing reflective journals of community experience allowed learners to evaluate their progress. "I have been in green New Zealand for three years," wrote Win (China). "Now I can see how far I have come." Twelve students used a spatial metaphor to describe their increased involvement with New Zealand: the comparative closer. Dana (China), for example, wrote: "Community placement made New Zealand become closer and more real to me." Again, the theme of a journey of increased closeness, increased realness emerged. The data contain similarly expressive comparative adjectives, particularly more (11 cases). Qing (China) wrote, "I have gained more English language skills, cultural knowledge, and more work confidence."

The recurrence of real (12 cases) signals the value of learning capital beyond the classroom and a transition from being the student in the artificial classroom to being a community member in the real world. Hwang (Korea) "learned a lot of things," including taboo language (graphically cited) via "real conversation with native speakers in New Zealand." The reality of the community exists in contradistinction to the classroom. This is what Eva (China), one of four students to make such a comment, meant when she observed, "Speaking with different people about new topics is helpful to my learning, in contrast to learning in the classroom." Similarly, Li (China) commented that being "in a community by a real practice is a way of knowing more things about New Zealand, which we may not know in class." "In addition," she added, "I can be my real self."

Sam (Malaysia), who wrote, "My community placement gave me lots of confidence," is one of the 20 students who observed that socialization enhanced her sense of herself as a communicator. This theme was echoed by Jean (China), a kindergarten volunteer: "Working in a relaxed and friendly environment definitely can help with advancing my language fluency and my understanding of New Zealand colloquial language." The learning she quantified here was not only an increase in oral self-confidence, but also increased awareness of the spoken vernacular. In her journal, Jean positioned herself reflectively, creating a retrospective $I$ that developed into the more confident present self. In a similar vein, Topaz (Korea) wrote that community placement "made me become brave, I had to open my mouth and ask people if I could work in their workplace." Ivor (China), a volunteer at an aquarium, wrote with dramatic surprise and pride as he constructed his subject position at the end of his first day, "Well, well, I believe my confidence in English helps me to stay in this community."

Martinus (Sweden), in a hostel, wrote. "Just to sit down with total strangers and have conversations about a bit of everything, not too deep and personal things but small talk, is absolutely amazing and a part of myself I didn't get to know before I came here." Delight in small talk as a form of interaction unavailable in school emerged as a theme (12 students mentioned 
it) as did "adapting to Kiwi accent and slang" (mentioned by another 12 participants). Moreover, when learners were given a context for communication, their confidence increased. This is illustrated by Sam's comment: "Community placements have boosted my confidence and have taught me to be more attentive with instructions, flexible, organized, co-operative, and being more responsible with myself and the tasks provided."

Fifteen students positioned themselves metaphorically as subjects in the process of developing Kiwi identities. I mention Andreas (Romania) above: "When I first came to NZ ... I was like a newborn baby, and having this job helped me to understand and realize things that contribute to the culture of a country." Participation led to realization, and placement was a stage in the journey of discovery. Dana, who worked at Auckland's City Mission, noted that placement enabled her to "get in deep" and "put in both feet." She reflected on "how shallow" her knowledge of New Zealand had been when she acquired it only from television, other media, or shopping. She called her placement "this unforgettable life experience." Qing described the opening of her mind as if it were a landscape: "My mind opened wide and let in the air." Jordana (Thailand) linked her self-negotiation to an increasing sense of ease with the motu: "I have been to Rangitoto Island twice, and I am feeling that I am more appreciative of where I am and who I am."

This and the following cases exemplify how students used diaries as sites of self-reappraisal and self-renegotiation. First, Moira (China) articulated a moment of self-knowledge using the imagery of moving from being spectator to participant.

I have tried to take part in [Kiwi] social activities. However, I couldn't understand them at all. I felt that I am standing out of the door, I can see through windows, I can hear their sounds, I can copy their actions but I don't know why they do that ... now I do not worry about this. I have learned their culture, although not completely. I talk with them much more confidently and state my opinion.

Second, Miwa (Korea) reflected on a similar moment of self-realization using the metaphor of views from the outside and inside: "I have just been living in my own culture, not try to integrate the culture that I am living ... the positive outcome for me doing this paper is that I am trying to recognize real New Zealand culture and society. It is not from an outsider's view, but it's a view from a New Zealander, me."

\section{Participation in Community as Socialization}

Les (China), placed in a community center, described the process of his own language socialization. In his first entry, he wrote, "In order to participate into the society, I became one of the volunteers." The last words in his journal illustrate his progress via socialization: "I would like to do more work in the 
community. I really enjoyed helping people and would like to continue to do it." Somalian refugee and Citizen's Advice Bureau (CAB) volunteer Mora wrote: "I want to return something to this country which gave my family a home." He added, "I know I can do this with the CAB." Tim (Ethiopia) listed a range of literacy practices applied and skills gained through his tasks as a $\mathrm{CAB}$ volunteer, and he valued them for his future work with African refugees. Beth (China), working in a nursing home, wrote, "Being a volunteer gives me a chance to contribute to NZ society." She enjoyed giving back to the community.

Diana (China), placed in a Red Cross shop, realized her investment in community placement immediately and described her trajectory.

The original motivation for me was to plan ahead with my future career. As New Zealand work experience is demanded, I thought taking a volunteering job not only gives me an opportunity to participate in society and help other community members, but also affords me a window to observe New Zealand society, gain some experience in working ... and most importantly practice my English language.

Being a participant in a community simultaneously opened what a supervisor in a nursing home called "a window into cultural understanding." In addition to Diana, seven students referred to the future or career value of placements. For those who were immigrants, its contribution to socializing into their idea of New Zealanders' lifestyle is explicit. May (China), in her first log, wrote, "I hope I can do well and fit in well," and in her final words, "the benefit ... it is very useful and I can adapt it to my lifestyle." Sophia wrote, "I have learned how to work with Kiwis." Ten of the students wrote that they would continue the volunteer work they had started via community placement. Malli (Hong Kong) wrote, "I will continue to do voluntary work either in rest [nursing] homes or other community centers in order to integrate into the society, as it is a good opportunity to learn more about New Zealand culture and society outside the class."

The feeling that the immersive situated experience of placement was a chance to apply Maori cultural knowledge was another important theme. Ivor imagined a conversation with a Maori co-worker: "I have also found a Maori working there as a fish feeder ... I would like to talk to him and apply my knowledge of Maori learned from [a Maori language and culture subject]. I think it will help me to have a good conversation." In his anecdote, he wrote,

He was funny. He said "chaofan" (fried rice) to me because he knows I am a Chinese. I was surprised. Then we started a conversation. I really wanted to have a good start, so I showed him my knowledge of Maori with asking his iwi's [tribe] name. I realized that understanding a culture could help me to integrate into a society easily. 


\section{Discussion}

These findings point to a range of practical implications about the teaching and learning opportunities that participating in and writing about community placement can have for participants. Applying Norton (2000), this discussion analyzes learners' journals in an effort to understand their linguistic, cultural, and social investments. As my discussion of metaphors suggests, the written form offers students the chance for vivid self-expression and reflective positioning that are not as likely to be found in spoken presentations.

The first finding focused on learners gaining awareness of their improved confidence in applying linguistic and pragmatic strategies in their local communities. Peter's narrative of himself as a volunteer serving food in a nursing home indicated not merely lexical development learning what a scone was and what fancy (verb) meant but also increased awareness of functional and pragmatic communication strategies and Gee's (1996) discourses in context. Participants emphasized their communicative progress with accounts of how attuned they had become to local idiom and how invested they were in acquiring lexis from real-world registers. Surprised micro-narratives of encountering and using idioms, slang, and profanity "real" language resonated through the journals. The learners worked in a Kiwi context, so their success was a payback for their investment in learning English in (and often for) New Zealand.

Students measured their increased sociocultural awareness not only through micro-narratives of language use, but also through stories that demonstrated their enhanced sensitivity to culture as a part of individuals' identities. Some students such as Rama began to demonstrate critical awareness of cultural maintenance as well and the dangers of overly assimilative thinking, whereas others such as Ivor positioned themselves as able to leverage into New Zealand society through acts of intercultural sensitivity. The act of reflective positioning in writing enacts the process of learners coming to understand the interconnectedness of language, increased cultural awareness, and identity negotiation that many writers since McKay and Wong (1996) have observed. They instantiate the reflective positioning that Pavlenko and Blackledge (2005) view as central to pedagogical interventions whereby students construct their subjectivities and personalized written constructions of themselves as increasingly socioculturally aware language-learners.

The second finding illustrates that journals about placements, like autobiographies or learning histories, map out journeys of self where newer, more real, more enlightened selves reflected on their progress as language-learners, observer-participant members relative to Kiwi culture and communities, and as social agents. Topaz's "becoming brave" through spoken interaction testified to her changing self: the language-learner as risk-taker. Li's realization that she could be her real self in the community, as opposed to having a cultivated face identity in the classroom (where other Chinese students might 
judge and measure her), was a revelation at a personal level. Ivor's rhetorical surprise at being accepted as an English-speaker during his placement revealed for him the possibility that membership of communities that he had only imagined might become real, even the fulfillment of his dream of integration (his word). To encourage students to imagine themselves as participants in desired communities is a powerful pedagogical tool (Kanno \& Norton, 2003). Like Andreas in my opening quote, Ivor negotiated the socially available possibilities for selfhood that Ivanic (1998) discovered.

The journals represent evidence of surprise at individuals' own capacities and self-knowledge about their unrealized relationship to Kiwi culture. These are stories about becoming, not just learning. Demonstrating the claims of Myles and Cheng (2003), both Miwa and Moira speak of progressing from feeling like outsiders to being closer to the inside. I see this as a metaphor for the power of community placement to allow people to find out who they can become and of the journal's potential to allow writers to see it for themselves. Arguably, this is also the Wengerian (1998) movement from legitimate peripheral participation to a fuller sense of being in community. For Miwa, the view into New Zealand society that was afforded her through participation in community and reflection in her journal is constitutive of her identity: a migrant stepping from the enclave into the soccer club. Such stories suggest that the more language socialization occurred, the closer students felt to Kiwi identities and to practising the target language. The community placement provided the context and catalyst for students' realizations: what Norton (2000) labels surprises and what Barnett (2004) dubs "ontological turns" (p. 247).

Third, as the stories of Ivor, Miwa, and Moira testify, placements can provide the language socialization necessary for observing and participating in situated contexts conducive to witnessing authentic discourse. At the same time, the process of narrating stories of the self as a developing agent in episodes of socialization was empowering. Malli, Beth, and Les wrote of their realizations that they enjoyed working with people in community contexts, and two of the participants who were also refugees, Mora and Tim, wrote of their resolve to continue with their social work. Ivor's story of speaking with a Maori colleague while also illustrating the notion of surprise was illuminating in other ways. This reflective positioning and creation of the subject Ivor demonstrated the potential of linguistic exchanges to build cultural bridges; the importance of humor in showing affect; the necessity of preparing learners with bicultural knowledge before a community placement event; and finally, the potential role of cultural knowledge and experience in socialization and integration.

The practical and pedagogical implications of this study are that teachers of language and culture are "in a powerful positions to help create ... imagined communities and to stimulate ... them" (Murphey, Chen, \& Chen, 2005, p. 84). Instructors can achieve this largely by being "intercultural inter- 
preters" (Dlaska, 2000, p. 256), preparing learners for experience in the real world, and by being "masters of the Discourse or Discourses to which they are apprenticing their learners" (Gee, 2004, p. 30) so that they can prepare learners linguistically, socioculturally, and pragmatically for community placements. Combining community placement with journal-writing not only allows students to practice producing text, but also to create narratives in which they can empower themselves as learners and global citizens. As Norton (2000) remarks, this affords them opportunities to "interrogate their relationship to larger social processes" (p. 153). Discovering you are useful to society is affirmative learning indeed.

\section{Limitations}

The fact that these data were collected as part of an assessment task affects the type of discourse produced. However, the students' diaries remain hugely authentic. The aim was to collect students' impressions, observations, reflections, and experiences as thick description. This method is grounded by knowledge that autobiographical writing captures a self "below the level of consciousness" (Ivanic, 1998, p. 25). It can also capture learning trajectories (Norton, 2000; Pavlenko, 2001, 2002). The validity of the themes emerging from the data is strengthened by the fact that the data were collected from participants over six semesters (three years).

\section{Conclusions}

Community placement is a valuable pedagogical intervention that bridges the classroom and the real world. As a practical innovation, it responds to the needs of EAL learners: immigrants, refugees, international students, and study-abroad students. It also responds to researchers writing from sociocultural, literacy, social constructivist, and poststructuralist perspectives. It acknowledges Barnett (2004), who argues that higher education programs need to foster authentic being as graduates face unknown futures in globalized workforces and communities. The type of independent culture-learning described in the diaries occurred because meaningful contexts for "unfamiliar freedom" were created (Dlaska, 2000, p.258) in the form of scaffolded community placements. These meaningful contexts provided students with valuable opportunities for socialization. Community placements activate Gee's (1992) social mind opening a door to a situated world of authentic discourses.

The voices that students heard during placements were affirmative beyond merely offering feedback and reflection on individuals' and communities' linguistic and cultural practices. They variously corroborated classroom learning, provided examples and models of real speakers, and held up a mirror in which participants could see how far they had come as individuals on life journeys, not just as students. The voices and home-wisdoms of local English-speakers can have a lasting effect on learners and can affect their de- 
veloping senses of identity in their host communities, cultures, and countries. Fundamental is the Wengerian (1998) idea that learners move from legitimate peripheral participation to becoming full persons with agency. Community placements combined with journal writing create a pedagogy for authentic being (Barnett, 2004). By providing opportunities for socialization and reflection, placements can inspire confidence and affect with a range of cultural capital. Part of this capital, this study shows, is enacting the process of entering an imagined community and engaging with identities in ways not previously believed possible. Through community placements, EAL learners can develop linguistically, culturally, and ontologically.

This project also demonstrates how reflective autobiographical journals function, with students capturing and reflecting on their individual investments in their language and learning of culture. Students position themselves retrospectively as both students on an assignment and as individuals with agency, and what emerges are images that link their current status and performance in communities and their desire to belong to future and imagined communities. In journals, learners' identities become subjectivities. Through autobiographical storytelling, learners identify, describe, and reflect on moments of confidence, awareness, and surprise. The surprises they describe demonstrate enhanced cultural and self-awareness. Writing narratives of experience and progress places the participants/writers center stage, allowing them to see that they have developed agency and begun to show a certain comfort with their new identity, characterized as an "indwelling in themselves" (Barnett, 2004, p. 257). Learners chart individual journeys from feeling like a newborn baby to gaining a window into both the host culture and their own communicative and humanitarian capacity. Participating in real communities opens a range of future imagined communities. As Norton (2000) discovered, this directed pedagogical use of diaries as chronicles of experience allows students to develop as learners and as participants in culture and to find environments that enhance human possibility.

\section{The Author}

Martin Andrew lectures in writing at Swinburne University in Melbourne with particular interests in community learning, language and identity, doctoral supervision, and expressiveness in e-communities. As a lecturer and researcher at Unitec New Zealand, he undertook a study of the value of the volunteer sector for linguistic and cultural learning for learners of English as an additional language from 2005 until 2009.

\section{References}

Anderson, B. (1983). Imagined communities: Reflections on the origin and spread of nationalism. New York: Verso.

Andrew, M., \& Kearney, C. (2007). Practicing in and learning from community placements.

New Zealand Applied Studies in Linguistics, 13, 31-45.

Barnett, R. (2004). Learning for an unknown future. Higher Education Research and Development, 23, 247-260. 
Barton, D., Hamilton, M., \& Ivanic, R. (2000). Situated literacies. London: Routledge.

Benson, P. (2005). (Auto)biography and learner diversity. In P. Benson \& D. Nunan (Eds.), Learners' stories: Difference and diversity in language learning (pp. 4-21). Cambridge, UK: Cambridge University Press.

Blue, G. (1990). Language learning within academic constraints. (ERIC Document Reproduction No. ED390298)

Boude, D., Keogh, R., \& Walker, D. (1985). Reflection: Turning experience into learning. London: Kogan Page.

Cooke, D. (2001). Lives on hold: ESL in a restructured society. TESL Canada Journal, 18, 65-77.

County of Wellington, Ontario. (2011). Community placement. Available: http:/ / www.wellington.ca/social_subsection.aspx?id=28

Davies, B., \& Harre, R. (1990). Positioning: The discursive production of selves. Journal for the Theory of Social Behaviour, 20, 43-63.

Denzin, N., \& Lincoln, Y. (Eds.). (2000). Handbook of qualitative research (2nd ed.). Thousand Oaks, CA: Sage.

Dlaska, A. (2000). Integrating culture and language learning in institution-wide language programmes. Language, Culture and Curriculum, 13, 247-263.

Dudley, L. (2007). Integrating volunteering into the adult immigrant second language experience. Canadian Modern Language Review, 63, 539-561.

Duff, P. A. (2007). Second language socialization as sociocultural theory: Insights and issues. Linguist, 40, 309-319.

Furnham, A., Bochner, S., \& Lonner, W. (1986). Culture shock: Psychological reactions to unfamiliar environments. London: Methuen.

Gee, J.P. (1992). The social mind: Language, ideology, and social practice. New York: Bergin \& Garvey.

Gee, J.P. (1996). Social linguistics and literacies: Ideology in discourses (2nd ed.). London: Taylor \& Francis.

Gee. J.P. (2004). Situated language and learning: A critique of traditional schooling. London: Routledge.

Grey, M. (2009). Ethnographers of difference in a critical EAP community-becoming. Journal of English for Academic Purposes, 8, 121-133.

Hartmann, S. (2010). Study abroad at universities in New Zealand and Australia. Available: http://www.transitionsabroad.com/listings/study/articles/study-abroad-in-australianew-zealand-direct-enrollment.shtml

Haneda, M. (1997). Second language learning in a "community of practice": A case study of adult Japanese learners. Canadian Modern Language Review, 54, 11-27.

Heikinheimo, P., \& Shute, J. (1986). The adaptation of foreign students: Student views and institutional implications. Journal of College Student Personnel, 27, 399-406.

Hitchcock, G., \& Hughes, D. (1993). Models of social research. In G. Hitchcock \& D. Hughes (Eds.), Research and the teacher: A qualitative introduction to school-based research (2nd ed., pp. 12-46). London: Routledge.

Ivanic, R. (1998). Writing and identity. Amsterdam: John Benjamins.

Kanno, Y., \& Norton, B. (2003). Imagined communities and educational possibilities: Introduction. Journal of Language, Identity, and Education, 2, 241-249.

Kathpalia, S., \& Heah, C. (2008). Reflective writing: Insights into what lies beneath. RELC Journal, 3, 300-317.

Keesing, R.M. (1982). Theories of culture. In R.W. Casson (Ed.), Language, culture and cognition: Anthropological perspectives (pp. 42-66). New York: Macmillan.

Kramsch, C. (1998). The privilege of the intercultural speaker. In M. Byram \& M. Fleming (Eds.), Language learning in intercultural perspective (pp. 16-31). Cambridge, UK: Cambridge University Press. 
Kristeva, J. (1986). A question of subjectivity: Interview with S. Sellers. Women's Review, 12, 19-22.

Lave, J., \& Wenger, E. (1991). Situated learning: Legitimate peripheral participation. Cambridge, UK: Cambridge University Press.

Li, J. (2009). From classroom to imagined community: A study of three learners of Crazy English in China. Prospect, 24, 49-67.

McKay, S.L., \& Wong, S.C. (1996). Multiple discourses, multiple identities: Investment and agency in second language learning among Chinese adolescent immigrant students. Harvard Educational Review, 66, 577-609.

Morita, N. (2004). Negotiating participation and identity in second language academic communities. TESOL Quarterly, 38, 573-603.

Murphey, T., Chen, J., \& Chen, L. (2005). Learners' constructions of identities and imagined communities. In P. Benson \& D. Nunan (Eds.), Learners' stories: Difference and diversity in language learning (pp. 83-100). Cambridge, UK: Cambridge University Press.

Myles, J., \& Cheng, L. (2003). The social and cultural life of non-native English speaking international graduate students at a Canadian university. Journal of English for Academic Purposes 2, 247-263.

Newton, J., Yates, E., Shearn, S., \& Nowitzki, W. (2010). An introduction to the concept of intercultural communicative language teaching and learning: A summary for teachers. Wellington: New Zealand Ministry of Education.

Norton, B. (2000). Identity and language learning: Gender, ethnicity, and educational change. London: Longman.

Norton, B. (2001). Non-participation, imagined communities, and the language classroom. In M. Breen (Ed.), Learner contributions to language learning: New directions in research (pp. 159171). Harlow, UK: Pearson Education.

Norton, B. (2010). Language and identity. In N. Hornberger \& S. McKay (Eds.), Sociolinguistics and language education (pp. 349-369). Clevedon, UK: Multilingual Matters.

Norton, B., \& Toohey, K. (2001). Changing perspectives on good language learners. TESOL Quarterly, 35, 307-322.

Pavlenko, A. (2001). "In the world of the tradition, I was unimagined." Negotiation of identities in cross-cultural autobiographies. International Journal of Bilingualism, 5, 317-344.

Pavlenko, A. (2002). Poststructuralist approaches to the study of social factors in L2. In V. Cook (Ed.), Portraits of the L2 user (pp. 277-302). Clevedon, UK: Multilingual Matters.

Pavlenko, A., \& Blackledge, A. (2005). Introduction: New theoretical approaches to the study of negotiation of identities in multilingual contexts. In A. Pavlenko \& A. Blackledge (Eds.), Negotiation of identities in multilingual contexts (pp. 1-33). Clevedon, UK: Multilingual Matters.

Pavlenko, A., \& Lantolf, J. (2000). Second language learning as participation and the (re)construction of selves. In J.P. Lantolf (Ed.), Sociocultural theory and second language learning (pp. 157-180). Oxford, UK: Oxford University Press.

Peterson, E., \& Coltrane, B. (2003). Culture in second language teaching. ERIC Document Reproduction No. ED OFL0309.

Pittaway, D.A. (2004). Investment and second language acquisition. Critical Inquiry in Language Studies, 1, 203-218.

Sandelowski, M. (1995). Qualitative analysis: What it is and how to begin. Research in Nursing and Health, 18, 371-375.

Sercu, L. (2002). Autonomous learning and the acquisition of intercultural communicative competence: Some implications for course development. Language, Culture and Curriculum, 15, 61-74.

Swain, M., Kinnear, L., \& Steinman, L. (2010). Sociocultural theory in second language education: An introduction through narrative. Clevedon, UK: Multilingual Matters. 
Wenger, E. (1998). Communities of practice. Cambridge, UK: Cambridge University Press. Zimmerman, S. (1995). Perceptions of intercultural communication competence and international student adaptation to an American campus. Communication Education, 44, 321-335. 